(c) 2001 Blackwell Publishing, Inc.

The definitive version is available at www.blackwell-synergy.com

\title{
Comparative effects of long-term hypoxia on growth, feeding and oxygen consumption in juvenile turbot and European sea bass
}

\author{
K. Pichavant ${ }^{1}$, J. Person-Le-Ruyet ${ }^{1}$, N. Le Bayon ${ }^{1}$, A. Severe ${ }^{1}$, A. Le Roux ${ }^{1}$ and G. Boeuf ${ }^{1,2}$ \\ ${ }^{1}$ Laboratoire Adaptation, Reproduction and Nutrition, Ifremer, Centre de Brest, BP 70, 29280 Plouzane, France \\ 2 Present address: Laboratoire Arago, Observatoire Océanologique, CNRS/Université Pierre et Marie Curie, \\ 66651 Banyuls-sur-mer, France.
}

*Author to whom correspondence should be addressed at present address: Laboratoire de Biologie et Physiologie Cellulaires, UFR Sciences et Techniques, Université de Bretagne occidentale, 6 avenue Le Gorgeu, BP 809 29285 Brest Cédez, France. Tel.: +33 029801 72 60; fax: 3302980163 11; email: Karine.Pichavant@univbrest.fr.

\begin{abstract}
When juvenile turbot Scophthalmus maximus and sea bass Dicentrarchus labrax were fed to satiation, growth and food intake were depressed under hypoxia $\left(3.2 \pm 0.3\right.$ and $\left.4.5 \pm 0.2 \mathrm{mg} \mathrm{O}_{2} \mathrm{I}^{-1}\right)$. However, no significant difference in growth was observed between fishes maintained in hypoxia and fed to satiation and fishes reared in normoxia $\left(7 \cdot 4 \pm\left. 0.3 \mathrm{mg} \mathrm{O}_{2}\right|^{-1}\right)$ and fed restricted rations (same food intake of fishes at $3.2 \mathrm{mg} \mathrm{O}_{2} \mathrm{I}^{-1}$ ). Routine oxygen consumption of fishes fed to satiation was higher in normoxia than in hypoxia due to the decrease in food intake in the latter. Of the physiological parameters measured, no significant changes were observed in the two species maintained in hypoxia. This study confirms the significant interaction between environmental oxygen concentrations, feeding and growth in fishes. Decrease in food intake could be an indirect mechanism by which prolonged hypoxia reduces growth in turbot and sea bass, and may be a way to reduce energy and thus oxygen demand.
\end{abstract}

Keywords: turbot; sea bass; hypoxia; growth; oxygen consumption 


\section{INTRODUCTION}

Acute decreases in water oxygen $\left(\mathrm{O}_{2}\right)$ concentrations may occur in intensive fish farming, especially when fishes are reared at high densities. Considerable attention has been paid to oxygen, as low ambient $\mathrm{O}_{2}$ concentrations are known to affect growth, food consumption and physiological state of fishes (Jobling, 1994). $\mathrm{O}_{2}$ levels at which the decrease in growth is observed vary according to the species. In coho, Oncorhynchus kisutch (Walbaum) and sockeye salmon O. nerka (Walbaum), largemouth bass Micropterus salmoides (Lacépède) and carp Cyprinus carpio (L.), growth is afffected by $\mathrm{O}_{2}$ concentrations $<4-5 \mathrm{mg} \mathrm{l}^{-1}$ (Brett, 1979; Brett \& Blackburn, 1981). In rainbow trout, O. mykiss (Walbaum), the $\mathrm{O}_{2}$ concentration threshold for growth is much higher, $7 \mathrm{mg} \mathrm{l}^{-1}$ (Pedersen, 1987).

Most of the studies on the relationship between $\mathrm{O}_{2}$ and growth have been conducted on freshwater fish species. The present study was undertaken to examine the interactions between oxygen availability and growth in two, economically important, marine fishes, turbot Scophthalmus maximus (L.) and sea bass Dicentrarchus labrax (L.). In a previous study (Pichavant et al., 2000), it was shown that in juvenile turbot growth was reduced when these fishes were maintained in hypoxic water (5.0 $\mathrm{mg} \mathrm{O}_{2} \mathrm{l}^{-1}$ ). It was hypothesized that one of the mechanisms by which long-term hypoxia reduced growth in juvenile turbot was a decrease in food intake. This hypothesis is tested in the present study.

\section{MATERIALS AND METHODS}

\section{FISH AND EXPERIMENTAL DESIGN}

Experiments were carried out with 6 to 8 month old hatchery-reared juvenile turbot and sea bass over 42 days in $1 \mathrm{~m}^{2}$ tanks, with a water volume of $450 \mathrm{l}$. The tanks were supplied with a continuous water flow, with an exchange rate of $10 \mathrm{l} \mathrm{min}^{-1}$. Before the experiments, the fishes were maintained at 34 \%o salinity, 16L:8D photoperiod, $2 \mathrm{~W} \mathrm{~m}^{-2}$ light intensity at the water's surface and within the optimal temperature range for growth, $17.0 \pm 0.5^{\circ} \mathrm{C}$ for turbot (Burel et al., 1996) and $22.0 \pm 0.5^{\circ} \mathrm{C}$ for sea bass (J. Person-Le-Ruyet, pers. obs.).

The fishes [initial mass: $66.3 \pm 0.5 \mathrm{~g}$ (S. E.) for turbot and $60.8 \pm 0.6 \mathrm{~g}$ (S. E.) for sea bass] were divided into eight groups of 80 turbot and eight groups of 65 sea bass and randomly assigned to the experimental tanks. They were then allowed to acclimate to the environmental and feeding conditions for 4 weeks in normoxic seawater (7.4 $\mathrm{mg} \mathrm{O}_{2} \mathrm{l}^{-1}$ ). The fishes were manually fed twice a day at 0800 hours (morning meal) and 1600 hours (evening meal) to apparent satiation. A commercial dry pellet adapted to each species was used [Le Gouessant ${ }^{\circledR}, 4.5 \mathrm{~mm}$ diameter, total protein (54\% of dry matter) and crude fat (12\% of dry matter) for turbot and Biomar ${ }^{\circledR}, 3 \mathrm{~mm}$ diameter, total protein (45 \% of dry matter) and crude fat (21.5\% of dry matter) for sea bass]. Food intake was measured after each meal.

After acclimatization, the following experiments were performed in duplicate on both species for 42 days: Reared in $3.2 \mathrm{mg} \mathrm{O}_{2} \mathrm{l}^{-1}$ water and fed to apparent satiation (food intake was assumed to be equal to that provided); reared in $4.5 \mathrm{mg} \mathrm{O}_{2} \mathrm{l}^{-1}$ water and fed to apparent satiation; reared in normoxic condition $\left(7.4 \mathrm{mg} \mathrm{O}_{2} \mathrm{l}^{-1}\right.$ ) and fed to apparent satiation; reared in normoxic condition $\left(7.4 \mathrm{mg} \mathrm{O}_{2} \mathrm{I}^{-1}\right)$ and fed restricted 
rations. These rations were equal to the mass of food ingested per fish reared in $3.2 \mathrm{mg} \mathrm{O}_{2} \mathrm{l}^{-1}$ water.

At the beginning of the experiments, the hypoxic tanks were supplied with $\mathrm{O}_{2}$ deprived water. The hypoxic levels were achieved within $4 \mathrm{~h}$ and were maintained throughout the experiments. Hypoxic water was obtained using an oxygen depletion system described by Pichavant et al. (2000). Oxygen depletion was controlled by nitrogen flow, and total gas pressure was measured with a tensionometer (300C Novatech $^{\circledR}$ ). Normoxia was obtained by adding oxygen instead of nitrogen. Surface gas exchange in the tanks was limited by directing the inflow under water. The $\mathrm{O}_{2}$ concentration in each tank was monitored continuously according to the method described by Gaumet et al. (1995). During the 42 day period, the $\mathrm{O}_{2}$ concentrations were $3.2 \pm 0.3,4.5 \pm 0.2$ and $7.4 \pm 0.3 \mathrm{mg} \mathrm{l}^{-1}$.

\section{GROWTH AND FEEDING}

Every 2 weeks, the fish from each tank were fasted for $18 \mathrm{~h}$ and individually weighed to the nearest $0.1 \mathrm{~g}$. No anaesthesia was used for turbot. Sea bass were anaesthetized in a solution of ethylene-glycol-monophenyl-ether (0.5\%) before weighing. Apparent food conversion efficiency $\left(E_{c}\right)$ was calculated as $\left(W_{2}-W_{1}\right) C^{-1}$ where $\mathrm{W}_{2}$ and $\mathrm{W}_{1}$ are wet masses ( $\mathrm{g}$ ) at days $\mathrm{t}_{2}$ and $\mathrm{t}_{1}$ respectively and $\mathrm{C}$ is food intake (dry mass in g) in the period. Daily feeding (F) was calculated from $F=100 C_{T} W^{-1}$ where $\mathrm{C}_{\mathrm{T}}$ is the mean daily mass ( $\mathrm{g}$ ) of dry food ingested and $\mathrm{W}$ is the mean wet fish biomass (g).

\section{OXYGEN CONSUMPTION}

Oxygen consumption $\left(\mathrm{MO}_{2}, \mu \mathrm{mol} \mathrm{O}_{2} \mathrm{~g}^{-1} \mathrm{~h}^{-1}\right)$ was determined according to the method described by Gaumet et al. (1995). Every hour during a $24 \mathrm{~h}$ period, the $\mathrm{O}_{2}$ concentration ( $\mu \mathrm{mol} \mathrm{l^{-1 }}$ ) in inflowing $\left(\mathrm{X}_{\mathrm{i}}\right)$ and outflowing $\left(\mathrm{X}_{0}\right)$ water was measured. $\mathrm{MO}_{2}=\mathrm{Q}_{\mathrm{w}}\left(\mathrm{X}_{\mathrm{i}}-\mathrm{X}_{\mathrm{o}}\right) \mathrm{W}^{-1}$ where $\mathrm{Q}_{\mathrm{w}}\left(\mathrm{l} \mathrm{h}^{-1}\right)$ is the water flow through the tank, and $\mathrm{W}$ ( $\mathrm{g}$ ) is the body mass. Only the mean hourly $\mathrm{MO}_{2}$ values obtained from three consecutive $24 \mathrm{~h}$ periods from day 36 to day 39 are given, as they are representative for the two species throughout the experiments.

\section{BLOOD PARAMETERS}

At day 1, 7, 14, 28 and 42, samples of blood (obtained by cardiac puncture) and liver (immediately frozen in nitrogen) were taken from 12 fish per experiment (6 fish per tank) which had been fasted for $18 \mathrm{~h}$. Haematocrit and blood $\mathrm{pH}$ (Metrohm ${ }^{\circledR}$ pHmeter fitted with a Fermprobe ${ }^{\circledR}$ microflow pH sensor) were determined immediately after blood sampling. Plasma total $\mathrm{CO}_{2}$ concentration was measured within 15 min using a Sigma Diagnostics enzymatic kit (132-UV). All other blood parameters were measured on frozen plasma samples: osmolarity using an Advanced Instrument Osmometer $^{\circledR}$; chloride by argentimetric titration using a Radiometer CMT $10^{\circledR}$ as described by Gaumet et al. (1995); glucose and lactate concentrations using enzymatic kits (16-UV Sigma Diagnostics and 256773 Boehringer-Mannheim, respectively). Plasma concentration of tri-iodothyronine $\left(\mathrm{T}_{3}\right)$ in turbot and sea bass and thyroxine $\left(\mathrm{T}_{4}\right)$ in turbot was measured using specific radio-immunoassay methods (Boeuf et al., 1989). Liver glycogen was determined according to the method of Carr \& Neff (1984). At the end of the experiments, 12 other fish per experiment (6 per tank) were sacrified in a lethal solution of ethylene-glycol-monophenyl-ether (2.5\%) and blood was sampled for plasma cortisol analysis by the radio-immunoassay method (Lamers, 1992). 


\section{DATA ANALYSIS}

Statistical analysis were conducted using STATISTICA for Windows. ANOVA tests were used as the homogeneity of variances and normality of distribution were verified. The effects of $\mathrm{O}_{2}$ concentrations on growth, physiological parameters and $\mathrm{O}_{2}$ consumption were estimated using two-way ANOVA taking the tank effect into account. One-way ANOVA was used for food intake and food conversion efficiency analysis. Significant ANOVA were followed by a multiple comparison test (NewmanKeuls test). All the results are expressed as mean \pm S. E. Level of significance was taken as $P<0.05$.

\section{RESULTS}

\section{GROWTH PERFORMANCE AND FEEDING}

Mass increases in turbot and sea bass kept in hypoxia and fed to satiation were significantly less than in normoxic fishes fed to satiation [Fig. 1 (a), (b)]. In turbot and sea bass, mass gains throughout the 42 day period were similar in fishes at $3.2 \mathrm{mg} \mathrm{O}_{2} \mathrm{l}^{-1}$ and fed to satiation and those at $7.4 \mathrm{mg} \mathrm{O}_{2} \mathrm{l}^{-1}$ and fed restricted rations.

In turbot and sea bass fed to satiation, a significant decrease in the food intake (F) was observed when $\mathrm{O}_{2}$ decreased [Fig. 1 (c), (d)]. $\mathrm{F}$ was $\times 1.7$ to 1.8 lower in turbot and $\times 1.5$ to 1.7 lower in sea bass maintained at $3.2 \mathrm{mg} \mathrm{O}_{2} \mathrm{l}^{-1}$ than in fishes maintained at $7.4 \mathrm{mg} \mathrm{O}_{2} \mathrm{l}^{-1}$.

Food conversion efficiency $\left(E_{c}\right)$ was always higher in sea bass [1.2-1.6, Fig. 1(f)] than in turbot [0.7-1.0, Fig. 1 (e)]. In both species, $E_{c}$ were unaffected by oxygen concentration or feeding procedure. 
Fig. 1. Mean weight versus time in turbot $(1 \mathrm{~A})$ and sea bass $(1 \mathrm{~B})$ in relation to O2-concentration and feeding procedure: $3.2($ ), $4.5(\bullet)$ and $7.4($ ) mg O2 l-1 and fed to satiety, $7.4($ ) mg O2 l-1 and fedrestricted. Mean \pm SE ( $n=2$ replicates of 80 turbot each and 65 sea bass each). For every sample time, * indicates a statistical difference (p 0.05). a and b indicate intergroup statistical differences at day 42.

Feed intake (FI) and feed conversion ratio (FCR) versus time in turbot (1C and $1 \mathrm{E}$ ) and sea bass (1D and $1 \mathrm{~F}$ ) in relation to O2-concentration and feeding procedure: $3.2($ ), $4.5(\quad)$ and $7.4(\quad) \mathrm{mg}$ O2 l-1 and fed to satiety, 7.4 ( ) mg O2 l-1 and fed-restricted. Mean \pm SE (n = 2 replicates of 80 turbot each and 65 sea bass each). a, b and c indicate intergroup statistical differences ( $p \quad 0.05)$; NS = no significant difference between the experimental groups.
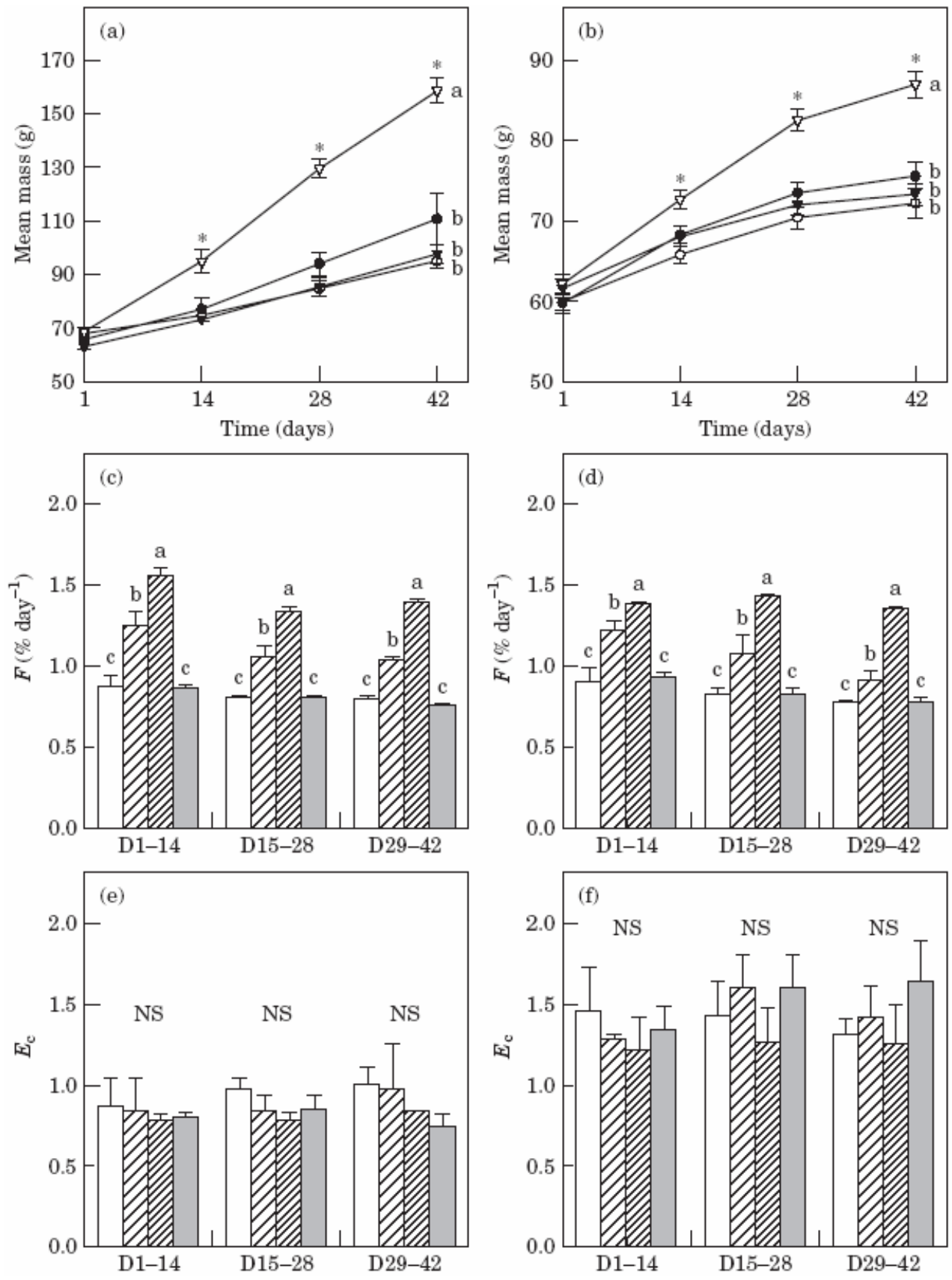


\section{OXYGEN CONSUMPTION}

In normoxic fed to satiation turbot, routine $\mathrm{O}_{2}$ consumption started to increase $2 \mathrm{~h}$ after each meal, and reached a maximum $3 \mathrm{~h}$ after the morning meal and 7-8 $\mathrm{h}$ after the evening meal [Fig. 2(a)]. Mean routine $\mathrm{O}_{2}$ consumption was significantly higher in normoxic fed to satiation than in hypoxic fed to satiation turbot [Fig. 2(c)].

In normoxic fed to satiation sea bass, a significant increase in routine $\mathrm{O}_{2}$ consumption was observed after the morning meal whereas a significant decrease occurred $1 \mathrm{~h}$ after the evening meal [Fig. 2(b)]. Mean routine $\mathrm{O}_{2}$ consumption was similar in fed to satiation sea bass reared at 7.4 and $4.5 \mathrm{mg} \mathrm{O}_{2} \mathrm{l}^{-1}$, and was significantly lower in fed to satiation sea bass maintained at $3.2 \mathrm{mg} \mathrm{O}_{2} \mathrm{l}^{-1}$ [Fig. 2(c)]. Mean $\mathrm{O}_{2}$ consumption was significantly higher in sea bass than in turbot whatever the experimental condition [Fig. 2(c)].

Fig. 2. Daily patterns of routine O2-consumption (MO2) in turbot (2A) and sea bass (2B) in relation to O2-concentration and feeding procedure from day 36 to 39: $3.2($ ), $4.5(\bullet)$ and $7.4($ ) mg O2 l-1 and fed to satiety, 7.4 ( ) mg O2 l-1 and fed-restricted. Mean MO2 rate of turbot ( ) and sea bass ( ) from day 36 to 39 (2C) in relation to O2-concentration and feeding procedure. Mean \pm SE (n $=2$ replicates of 80 turbot each and 65 sea bass each). a and b indicate intergroup statistical differences (p $0.05)$; NS = no significant difference between the experimental groups.

The horizontal bar on the $\mathrm{x}$-axis indicates the alternative periods of light and dark, and indicates feeding time.
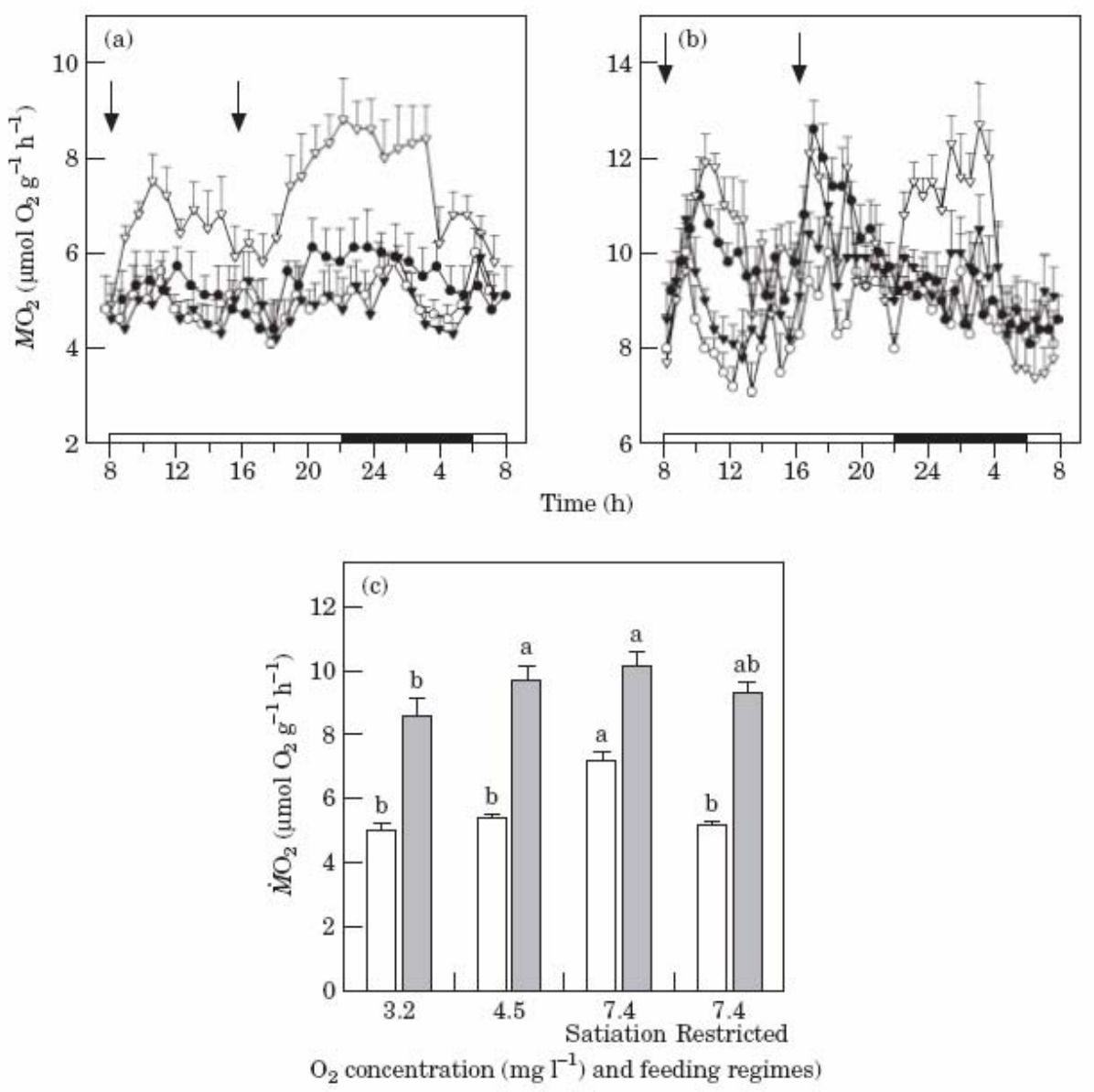


\section{EFFECTS OF HYPOXIA ON PHYSIOLOGICAL PARAMETERS}

All the measured physiological parameters, except for osmolarity in turbot, were unaffected by the experimental conditions (Tables I and II).

Table I. Blood parameters in turbot at day 42 in relation to $\mathrm{O}_{2}$ concentration and feeding procedure.

Mean \pm S.E. ( $n=2$ replicates of 80 turbot). a and $b$ significant differences $(P<0.05)$; NS = non significant.

\begin{tabular}{|c|c|c|c|c|c|}
\hline Oxygen concentration $\left(\mathrm{mg} \mathrm{l}^{-1}\right)$ & 3.2 & 4.5 & 7.4 & 7.4 & \\
\hline Feeding procedure & Fed to satiation & Fed to satiation & Fed to satiation & Restricted rations & \\
\hline Osmolarity (mosm l ${ }^{-1}$ ) & $318 \pm 1^{\mathrm{ab}}$ & $329 \pm 1^{a}$ & $325 \pm 1^{\mathrm{ab}}$ & $314 \pm 1^{b}$ & \\
\hline $\mathrm{Cl}^{-}\left(\mathrm{mmol} \mathrm{l}{ }^{-1}\right)$ & $143 \pm 3$ & $148 \pm 2$ & $143 \pm 1$ & $143 \pm 1$ & NS \\
\hline $\mathrm{pH}$ & $7.62 \pm 0.05$ & $7.52 \pm 0.01$ & $7.60 \pm 0.09$ & $7.60 \pm 0.05$ & NS \\
\hline Total $\mathrm{CO}_{2}\left(\mathrm{mmol} \mathrm{l}^{-1}\right)$ & $6.9 \pm 0.3$ & $7.1 \pm 0.2$ & $6.8 \pm 0.4$ & $6.7 \pm 0.5$ & NS \\
\hline Lactate (mmol l$\left.{ }^{-1}\right)$ & $0.33 \pm 0.04$ & $0.35 \pm 0.02$ & $0.31 \pm 0.01$ & $0.24 \pm 0.03$ & NS \\
\hline Glucose $\left(\mathrm{mmol} \mathrm{l}{ }^{-1}\right)$ & $2.5 \pm 0.1$ & $2.6 \pm 0.1$ & $2.7 \pm 0.1$ & $2.5 \pm 0.3$ & NS \\
\hline Liver glycogen $\left(\mu \mathrm{mol} \mathrm{g} \mathrm{fw}^{-1}\right)$ & $106 \pm 17$ & $148 \pm 55$ & $236 \pm 89$ & $87 \pm 28$ & NS \\
\hline Haematocrit (\%) & $21 \pm 1$ & $25 \pm 2$ & $24 \pm 1$ & $21 \pm 4$ & NS \\
\hline $\mathrm{T}_{3}\left(\mathrm{ng} \mathrm{ml}^{-1}\right)$ & $1.5 \pm 0.1$ & $1.7 \pm 0.1$ & $2.1 \pm 0.2$ & $1.6 \pm 0.3$ & NS \\
\hline $\mathrm{T}_{4}\left(\mathrm{ng} \mathrm{ml}^{-1}\right)$ & $2.6 \pm 0.3$ & $3.4 \pm 0.4$ & $3.8 \pm 0.6$ & $3.5 \pm 1$ & NS \\
\hline Cortisol (ng ml ${ }^{-1}$ ) & $2.6 \pm 1.4$ & $0.8 \pm 0.3$ & $2.5 \pm 1.2$ & $1.8 \pm 1.2$ & NS \\
\hline
\end{tabular}


Table II. Blood parameters in sea bass at day 42 in relation to $\mathrm{O}_{2}$ concentration and feeding procedure

Mean \pm S.E. ( $n=2$ replicates of 65 sea bass). NS = non significant.

\begin{tabular}{|c|c|c|c|c|c|}
\hline Oxygen concentration (mg l $\mathrm{l}^{-1}$ ) & 3.2 & 4.5 & 7.4 & 7.4 & \\
\hline Feeding procedure & Fed to satiation & Fed to satiation & Fed to satiation & Restricted rations & \\
\hline Osmolarity (mosm l-1) & $346 \pm 4$ & $335 \pm 12$ & $345 \pm 9$ & $342 \pm 1$ & NS \\
\hline $\mathrm{Cl}^{-}\left(\mathrm{mmol} \mathrm{l}{ }^{-1}\right)$ & $150 \pm 1$ & $147 \pm 4$ & $145 \pm 2$ & $145 \pm 2$ & NS \\
\hline $\mathrm{PH}$ & $7.64 \pm 0.14$ & $7.66 \pm 0.04$ & $7.72 \pm 0.05$ & $7.78 \pm 0.02$ & NS \\
\hline Total $\mathrm{CO}_{2}\left(\mathrm{mmol} \mathrm{l}^{-1}\right)$ & $7.2 \pm 0.5$ & $6.7 \pm 0.4$ & $7.1 \pm 0.2$ & $7.0 \pm 0.3$ & NS \\
\hline Lactate $\left(\mathrm{mmol} \mathrm{l}^{-1}\right)$ & $2.8 \pm 1.5$ & $3.0 \pm 1.8$ & $1.6 \pm 0.8$ & $2.2 \pm 0.5$ & NS \\
\hline Glucose $\left(\mathrm{mmol} \mathrm{l}^{-1}\right)$ & $5.7 \pm 1.3$ & $5.9 \pm 0.8$ & $5.7 \pm 1.9$ & $6.6 \pm 0.2$ & NS \\
\hline 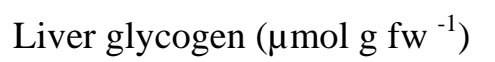 & $283 \pm 3$ & $340 \pm 14$ & $314 \pm 30$ & $339 \pm 6$ & NS \\
\hline Haematocrit (\%) & $38 \pm 2$ & $38 \pm 2$ & $32 \pm 2$ & $34 \pm 1$ & NS \\
\hline $\mathrm{T}_{3}\left(\mathrm{ng} \mathrm{ml}^{-1}\right)$ & $7.1 \pm 0.2$ & $7.1 \pm 0.2$ & $7.9 \pm 0.5$ & $7.5 \pm 0.2$ & NS \\
\hline Cortisol (ng ml ${ }^{-1}$ ) & $0.6 \pm 0.2$ & $0.7 \pm 0.2$ & $1.0 \pm 0.8$ & $0.9 \pm 0.6$ & NS \\
\hline
\end{tabular}




\section{DISCUSSION}

Exposure of juvenile turbot and sea bass to hypoxia induced a marked decrease in growth. This response is in agreement with previous data obtained by Thetmeyer et al. (1999) and Pichavant et al. (2000) in juvenile sea bass and turbot respectively. Two hypotheses have been made to explain the decrease in growth when fishes are exposed to long-term hypoxia: (1) an increase in energetic cost of ventilation which decreases the amount of energy available for growth (Kramer, 1987); (2) a decrease in food intake which allows fish to save energy (Brett, 1979; Kramer, 1987; Jobling, 1994). Only the latter was tested in the present study.

The search for food, digestion and assimilation are major components of the energy budget of fishes (Brett \& Groves, 1979). They can represent up to $60 \%$ of the total energetic expenditure of the animal (Van Dam \& Pauly, 1995). As in most fish species (Stewart et al., 1967; Adelman \& Smith, 1970; Carlson et al., 1980; Brett \& Blackburn, 1981; Pedersen, 1987; Thetmeyer et al., 1999), the food intake was strongly reduced when turbot and sea bass were exposed to hypoxia. In the present study, no significant difference in growth was observed between fishes reared in hypoxia and fed to satiation and those reared in normoxia and fed restricted rations. Thus, the decrease in food intake could be an indirect mechanism by which chronic hypoxia reduces growth in turbot and sea bass. The decrease in food intake probably reduces energy demand and therefore oxygen requirements.

Hypoxia apparently induces different effects on $E_{c}$ in fishes. A negative effect of hypoxia on $\mathrm{E}_{\mathrm{c}}$ was reported in juvenile largemouth bass (Stewart et al., 1967), rainbow trout (Pedersen, 1987) and Atlantic cod, Gadus morhua L. (Chabot \& Dutil, 1999). Thetmeyer et al. (1999) reported that $\mathrm{E}_{\mathrm{c}}$ was not affected by exposure of juvenile sea bass to hypoxia. Similarly, no significant difference in $E_{c}$ was reported in sea bass and turbot in the present study. The discrepancy between these studies could suggest that $E_{c}$ is more affected by the feeding procedure than by exposure to hypoxia.

The measurement of $\mathrm{O}_{2}$ consumption is an indirect way to estimate metabolism. The mean $\mathrm{O}_{2}$ consumption measured in routine metabolic conditions in turbot and sea bass maintained in normoxia was close to values previously reported in the two species (Waller, 1992; Burel et al., 1996; Claireaux \& Lagardère, 1999). In fishes maintained in normoxia and fed to satiation, mean routine $\mathrm{O}_{2}$ consumption was higher in sea bass than in turbot. This result could be explained by the difference in swimming activity between turbot, a benthic fish, and sea bass, a pelagic fish.

The routine $\mathrm{O}_{2}$ consumption was not constant during a $24 \mathrm{~h}$ period in turbot and sea bass. In turbot maintained in normoxia and fed to satiation, the ingestion of food was followed by an increase in $\mathrm{O}_{2}$ consumption i.e. an increase in the metabolic rate. This mechanism is known as specific dynamic action (SDA), and accounts for all the metabolic expenditures associated with digestion, absorption and storage of nutrients, deamination of amino acids, synthesis of excretory products and biosynthesis, turnover and deposition of tissue components (Jobling, 1981). In the present study, SDA was reduced when turbot were maintained in hypoxia due to the decrease in food intake.

In the sea bass maintained in normoxia and fed to satiation, feeding alone could not explain the fluctuations of routine $\mathrm{O}_{2}$ consumption. An increase in the routine $\mathrm{O}_{2}$ consumption was observed after the morning meal. This increase, as in turbot, may be attributed to SDA. The peak in $\mathrm{O}_{2}$ consumption observed in sea bass during the evening meal could be linked to the concomitant increased swimming activity (Brett \& Zala, 1975; Jobling, 1994). In the sea bass maintained in normoxia and fed to satiation, an 
increase in routine $\mathrm{O}_{2}$ consumption was observed during the night. As in the spotted grunter Pomadasys commersonnii Bloch (Du Preez, 1986), this increase could be due to a rise in the spontaneous swimming activity occuring during the night. When sea bass were maintained in hypoxia or fed restricted rations, such an increase was not observed. This result could suggest a decrease in swimming activity in hypoxia. Similar responses have been previously reported in white sturgeon, Acipenser transmontanus Richardson (Crocker \& Cech, 1997), dogfish Scyliorhinus canicula L. (Metcalfe \& Butler, 1984), rainbow trout (Buschnel et al., 1984), and sole Solea solea L. (Dalla Via et al., 1998).

When turbot and sea bass were maintained in hypoxia, no significant change in most of the physiological parameters measured was observed. Thus, when subjected to chronic hypoxia as low as $3.2 \mathrm{mg} \mathrm{O}_{2} \mathrm{l}^{-1}$, turbot and sea bass were able to successfully adjust their energy demand so as to avoid resorting to anaerobic metabolism (lactate production).

This investigation was supported by a grant from IFREMER. The authors thank P. Soulier and J. Lepioufle for their careful and critical reading of the manuscript.

\section{References}

Adelman, I. R. \& Smith, I. R. (1970). Effect of oxygen on growth and food conversion efficiency of northern pike. Progressive Fish-Culturist 32, 93-96.

Bœuf, G., Le Bail, P. Y. \& Prunet, P. (1989). Growth hormone and thyroid hormones during Atlantic salmon, Salmo salar L., smolting and after transfer to seawater. Aquaculture 82, 257-268.

Brett, J. R. (1979). Environmental factors and growth. In Fish Physiology, Vol. VIII, (Hoar, W. S., Randall, D. J. \& Brett, J.R., eds), pp. 599-675. New York: Academic Press.

Brett, J. R. \& Blackburn, J. M. (1981). Oxygen requirements for growth of young coho (Oncorhynchus kisutch) and sockeye (O. nerka) salmon at $15^{\circ} \mathrm{C}$. Canadian Journal of Fisheries and Aquatic Sciences 38, 399-404.

Brett, J. R. \& Groves, T. D. D. (1979). Physiological energetics. In Fish Physiology, Vol. VIII, (Hoar, W. S., Randall, D. J. \& Brett, J.R., eds), pp. 279-352. New York: Academic Press.

Brett, J. R. \& Zala, C. A. (1975). Daily pattern of nitrogen excretion and oxygen consumption of sockeye salmon (Oncorhynchus nerka) under controled conditions. Journal of the Fisheries Research Board of Canada 32, 2479-2486.

Burel, C., Person-Le Ruyet, J., Gaumet, F., Le Roux, A., Sévère, A. \& Boeuf, G. (1996). Effects of temperature on growth and metabolism in juvenile turbot. Journal of Fish Biology 49, 678-692. 
Buschnell, P. G., Steffensen, J. F. \& Johansen, K. (1984). Oxygen consumption and swimming performance in hypoxia-acclimated rainbow trout (Salmo gairdneri). Journal of Experimental Biology 113, 225-235.

Carlson, A. R., Blocher, J. \& Hermann, L. J. (1980). Growth and survival of channel catfish and yellow perch exposed to lower constant and diurnally fluctuating dissolved oxygen concentrations. Progressive Fish-Culturist 42, 73-78.

Carr, R. S. \& Neff, J. M. (1984). Quantitative semi-automated enzymatic assay for tissue glycogen. Comparative Biochemistry and Physiology 77B, 447-449.

Chabot, D. \& Dutil, J. D. (1999). Reduced growth of Atlantic cod in non-lethal hypoxic conditions. Journal of Fish Biology 55, 472-491. Doi : 10.1006/jfbi.1999.1005.

Claireaux, G. \& Lagardère, J. P. (1999). Influence of temperature, oxygen and salinity on the metabolism of the European sea bass. Journal of Sea Research 42, 157168.

Crocker, E. C. \& Cech, J. J. (1997). Effets of the environmental hypoxia on oxygen consumption rate and swimming activity in juvenile white sturgeon, Acipenser transmontanus, in relation to temperature and life intervals. Environmental Biology of Fishes 50, 383-389.

Dalla Via, J., Van den Thillart, G., Cattani, O. \& Cortesi, P. (1998). Behavioural responses and biochemical correlates in Solea solea to gradual hypoxic exposure. Canadian Journal of Zoology 76, 2108-2113.

Du Preez, H. H. (1986). Oxygen consumption of a shallow teleost the spotted grunter, Pomadasys commersonnii. Comparative Biochemistry and Physiology 84A, 61-67.

Gaumet, F., Boeuf, G., Sévère, A., Le Roux, A. \& Mayer-Gostan, N. (1995). Effects of salinity on the ionic balance and growth of juvenile turbot. Journal of Fish Biology 47, 865-876.

Jobling, M. (1981). The influences of feeding on the metabolic rate of fishes: a short review. Journal of Fish Biology 16, 629-638.

Jobling, M. (1994). Fish Bioenergetics, London: Chapman \& Hall.

Kramer, D. L. (1987). Dissolved oxygen and fish behavior. Environmental Biology of Fishes 18, 81-92.

Lamers, A. E., Flik, G., Atsma, W. \& Wendelaar Bonga, S. E. (1992). A rôle of diacetyl-alpha-melanocyte-stimulating hormone in the control of cortisol release in the teleost Oreochromis mosambicus. Journal of Endocrinology 135, 285-292. 
Metcalfe, J. D. \& Butler, P. J. (1984). Changes in activity and ventilation in response to hypoxia in unrestrained, unoperated dogfish (Scyliorhinus canicula L.). Journal of Experimental Biology 108, 411-418.

Pedersen, C. L. (1987). Energy budgets for juvenile rainbow trout at various oxygen concentrations. Aquaculture 62, 289-298.

Pichavant, K., Person-Le-Ruyet, J., Le Bayon, N., Sévère, A., Le Roux, A., Quéméner, L., Maxime, V., Nonnotte, G. \& Bœuf, G. (2000). Effects of hypoxia on growth and metabolism of juvenile turbot. Aquaculture 188, 103-114.

Stewart, N. E., Shumway, D. L. \& Doudoroff, P. (1967). Influence of oxygen concentration on growth of juvenile largemouth bass. Journal of the Fisheries Research Board of Canada 24, 475-494.

Thetmeyer, H., Waller, U., Black, K. D., Inselmann, S. \& Rosenthal, H. (1999). Growth of European sea bass (Dicentrarchus labrax L.) under hypoxic and oscillating oxygen conditions. Aquaculture 174, 355-367.

Van Dam, A. A. \& Pauly, D. (1995). Simulation of the effects of oxygen on feed intake and growth of Nile tilapia, Oreochromis niloticus (L.). Aquaculture Research 26, 427-440.

Waller, U. (1992). Factors influencing routine oxygen consumption in turbot, Scophthalmus maximus. Journal of Applied Ichthyology 8, 62-71. 